REVIEW PROF-2171

\title{
ORGAN TRAFFICKING;
}

Do you want a society where the destitute become a store for the wealthy?

Dr. Muhammad Nasir, Dr. Tehmina Nasir, Dr. Hira Ashraf Khan, Dr. Saba Khizar

Article Citation

Organ trafficking: do you want a society where the destitute become a store for the wealthy? Professional Med J 2013;20(2): 177181.

\section{INTRODUCTION}

Buyer is in desperate need of a human organ. Seller is destitute and needs cash to survive. The deal brings together two groups of people who have little in common. They are often from different cultures and speak different languages; ordinarily they would never meet. The only thing they share is desperation. The demand for organs and tissues worldwide is increasing much faster than organs donated voluntarily can meet, and the end result is leading to a spike in the number of people living in poverty offering to sell their organs on the black market.

"Organ trafficking is the recruitment, transport, transfer, harboring, or receipt of living or deceased persons or their organs by means of the threat or use of force or other forms of coercion, of abduction, of fraud, of deception, of the abuse of power or of a position of vulnerability, or of the giving to, or the receiving by, a third party of payments, or benefits to achieve the transfer of control over the potential donor for the purpose of exploitation by the removal of organs for transplantation".

Due to the prevalence of many cardiovascular diseases in today's society, the demand for transplanted organs is increasing. To meet this need, the international organ trafficking market is on the rise worldwide despite strict legislation throughout the world. Today, transplantation is commonly undertaken for numerous organs and tissue types, including the most commonly sold organ, the kidney. Less commonly transplanted organs include skin, blood and liver ${ }^{2}$. Although rare, the possible option of using dura mater, a membranous layer surrounding the brain, to replace the pericardial tissue sac around the heart cannot be ruled out ${ }^{3}$.

Even though medical science and technology have become advanced enough to carry out organ transplants, it should still be regarded as somewhat of a miracle. The very first kidney transplant only took place in 1954 when Doctor Joseph Murray and his medical staff transplanted a kidney in the United States of America at the Massachusetts General Hospital where the organ donor and recipient were identical twins. Kidney transplants from a live donor provide statistically significant chances of better survival and long-term success. This type of medical transplantation is now increasing and adding better quality of life in recipients ${ }^{4}$. With the help of advancements in medical technology and availability of immunosuppressive drugs, survival rates have increased dramatically. Today an organ transplant seems more a routine surgical procedure than a miraculous event. This routine nature of medical transplantation of organs from one living or dead body to another living body has caused major shortages in organs available, and has in turn led to a thriving black market in human organ sales and illegal organ procurement activities.

With advancements in medical science and research, there is a continuous increase in the success rates for the organ transplantation. There is an increasing population of persons who require organ 
transplantation due to the increased prevalence of chronic diseases. A large number of people are dying because of non-availability of genetically matched donors. Between 1990 and 2006, the patient-required solid organ transplantation waiting list has tripled in length ${ }^{5}$. Throughout the world, people found organ trafficking to be one of the easiest strategies for meeting the demand for transplantation organs. Developing countries have proved to be especially rich sources of supply. Trade is increasing for various reasons that include both medical and social needs ${ }^{6}$. Keeping in mind the cost difference of international organ transplantation and continuous care of a person requiring an organ transplant, some insurance companies have started paying for "transplant tourism," thereby indirectly promoting organ trafficking ${ }^{7}$.

There are many unfortunate stories where healthcare personnel have been involved in illegal trade in organs. These violations of human rights are reported in many underdeveloped countries such as India, Pakistan and Turkey. Most people travel to these countries where they can buy organs as package dealsfor $\$ 15,000$ $\$ 150,000$. The cost varies depending upon the needs of donors. Brokers are approached by people to buy and sell organs. While the brokers received the majority of the payment, the organ donors received only a few thousand dollars of compensation. In 2009, an example of this corruption was exposed in the United States where a broker paid $\$ 10,000$ to buy a kidney and charged the recipient $\$ 160,000$. For both parties, it is a matter of survival. The recipient wants to survive from an illness and the poor donor wants to escape poverty. These poor donors spent the money received to buy food and clothing for their families or to pay off debt. Unfortunately despite organ selling, they remain under the burden of debt and cannot bring much change to the lives of their families. Most donors are between the ages of 20 and 40 years and have low education status ${ }^{2}$.
These surgeries are performed at private for-profit hospitals that oftendo not adhere to international standards of medical practice and are not equipped for emergencies. Although there is no precise data available to explain the outcome of transplantation, a significant number of transplant rejection and disease transmission in recipients has been observed. Frequently these illegal procedures are performed by non-professional people using non-sterilized instruments which result in transplant rejection and communicable disease transmission like hepatitis $B$ and HIV $^{2}$.Many hospitals were reported by media where organs are retained after postmortem without informing the relatives ${ }^{8}$.

People in search of organs for transplantation frequently become victims of scams. In 2010, one healthcare professional in the Philippines collected $\$ 400,000$ from recipients living abroad, giving them false hope that organs are available ${ }^{9}$.The donors received insufficient immediate and continuing medical services after donation of their organs. In cases where medical problems arose from the transplant medical procedure, psychiatric problems were also reported ${ }^{10}$.An independent university based research project providing medical diagnostic facilities for the victims of organ trafficking revealed that organ donor face many post-surgical medical problems including kidney failure and hypertension due to substandard medical care and lack of medicine ${ }^{11}$.

According to Susanne (2010) ${ }^{12}$, some traffickers force or deceive the victims into giving up an organ. During an interview in a village in Moldova, victims said they were promised a visa for a developed country along with compensation and a job if they would donate an organ. After they donated their organ, promises were not fulfilled and only a small amount of compensation was ever paid. Susanne $(2010)^{12}$ also reported that some people were transported to various countries by brokers and were given jobs in restaurants. On payday, they were asked to donate their organ (mostly 
kidneys), if they needed their wages or wanted to go back home country. Demeny (2009) ${ }^{13}$ found some students in Romania advertised on the Internet to sell their organs to meet the financial needs of their education.

Organs taken from children as young as age 12 are medically suitable for transplantation. There have been unfortunate reports from Latin America where children were kidnaped and their organs were harvested. Some people adopted the children of poor families to obtain organs for transplantation. These children are then well fed to make them physically fit. When a suitable recipient is found after blood and tissue matching, they negotiate a high price for the healthy organ. Once the adult adoptive parent and adult buyer have agreed, without considering the welfare of the child donor, surgery is performed at a small clinic and doctors are paid a share for the surgery ${ }^{14}$.

China is among the most attractive destinations where international recipients travel for organ transplantation. In China, there are 68 offenses that carry the death penalty, and organs from these executed prisoners are often used for organ transplantation. Although the Chinese government denies this practice, this business is flourishing with the involvement of high officials. Prisoners are sometimes convicted and executed in order to increase the number of organs to sell to various hospitals ${ }^{15}$.

Wealthy people are at an advantage in gaining access to these organs. They pay poor people a small amount to buy organs and leave them at life's mercy with no follow-up long term medical care. International buyers pay more than local recipients. There is a great difference in currency conversion value between wealthy and poor countries. This trend of organ trafficking creates difficulties for locals who cannot afford to buy organs using their local resources. More local poor patients die because of non-affordability, while wealthy international recipients enjoy their lives after organ transplantation.

The estimated cost to buy and transplant a kidney is far less than a lifetime of kidney dialysis. The total annual cost of kidney dialysis programs in the USA for those suffering from kidney failure is $\$ 32.5$ billion, which is more than the total cost associated with kidney transplantation. Various studies provide evidence that the long term survival results of kidney dialysis are less than kidney transplants².

According to recent published data, more than 112,648 people in the United States are waiting for organs donations. According to organ procurement and transplantation network list, the most required organs are kidneys $(90,542)$ and livers $(16,035)$. The waiting time for new patients requiring organ transplantation is increasing every month. Approximately 4,000 new patients are added to this waiting list each month ${ }^{16}$. A longer waiting time to find a suitable matched organ for transplantation results in a longer period of sickness and inferior graft survival. Many human lives could be saved by decreasing the average wait time through availability of organs by means of organ trafficking. Offering financial incentives for organ donation would increase the number of willing donors ${ }^{17}$.

\section{CONCLUSIONS}

None of the benefits explained above address the exploitation of donors. This is especially true in an unregulated private market where compensation is poor and where there is little or no long term follow up care to protect the future health of donors. Enforceable internationally agreed upon regulation is needed.

Organ transplantation is a necessary treatment for many individuals whose organs have failed. Buying and selling organs is illegal all over the world, except in Iran, where living donors receive a monetary gift. Paid donors remain under the burden of debt and compromised body function after organ donation. 
Rich people have no reason to sell their organs. This imbalance is unfair and is not ameliorated by market mechanisms.

Trafficking in organ violates fundamental human rights. International organ trafficking is highly undesirable organized crime ${ }^{18}$.The recruiter, transporter, staff of hospital/clinic, doctor, middleman, contractor, buyer, and organ bank where organs are stored are all involved in the racket. It is also a fact that the entire racket is conducted in as much secrecy as possible and is rarely exposed. Justice for both donor and recipient is the best guide. Financial incentives from international buyers for organ donations must therefore be prohibited on grounds of exploitation of the poor.

Financial incentives in a regulated local market would increase the supply of organs and is ethically acceptable by people and states ${ }^{19}$. International organ trafficking should be banned for both buyers and sellers of organs. Nations should acknowledge two facts: (1) trafficking thrives because the organ shortage strongly motivates people on waiting lists in developed countries to buy organs where they can (third world countries), and (2) increasing the supply of organs will lead to reduction and eventual disappearance of organ trafficking. I believe we should attempt to increase the number of living donors by pursuing legalized alternative strategies. Government financial incentives in a regulated local market would increase the supply of organs.

To reduce or eliminate organ trafficking, countries should (1) reduce corruption and make strict laws to stop this crime, (2) increase legally obtained organ supply within country, (3) make laws to punish those held responsible severely, and (4) make laws requiring everyone and especially doctors to inform authorities immediately of any suspected organ trafficking. Copyright@C 20 Jan, 2013.

\section{REFERENCES}

1. Alrukhami, M., Chapman, J., Delmonico, F., Sayegh, M., Shaheen, F., \& Tibell, A. The declaration of Istanbul on organ trafficking and transplant tourism. Kidney International, 2008;74, 854-859. doi: 10.1038/ki.2008.388.

2. Jafar, T. H. Organ trafficking: Global solutions for a global problem. American Journal of Kidney Diseases, 2009;54(6), 1145-1157. doi: 10.1053/j.ajkd. 2009.08. 014.

3. Church, E. Organ donation and transplantation. Radiologic Technology Journal, 2002;73(6), 537-564.

4. Wolfe, R. A., Ashby, V. B., Milford, E. L., Ojo, A. O., Etten ger, R. E., Agodoa, L. Y., Held, P.J., Port, F. K. Comparison of mortality in all patients on dialysis, patients on dialysis awaiting transplantation, and recipients of a first cadaveric transplant. New England Journal of Medicine, 1999;341(23), 17251730. doi: 10.1056/NEJM199912023412303.

5. Weimer, D. L. Public and private regulation of organ transplantation: Liver allocation and the final rule. Journal of Health Politics, Policy and Law, 2007;32(1), 9-49. doi: 32/1/9.

6. Lock, M. M. Twice dead: Organ transplants and the reinvention of death, 2001.

7. Bramstedt, K. A., \& Xu, J. Checklist: Passport, plane ticket, organ transplant. American Journal of Transplantation, 2007;7(7), 1698-1701. doi: 10.11 11/j.1600-6143.2007.01847.x

8. Haddow, G. "Because you're worth it?" the taking and selling of transplantable organs. Journal of Medical Ethics, 2006;32, 324-328. doi: 10.1136/jme.2005. 013805 .

9. Samadi, D.B. Consequences of the rise in illegal organ trafficking. FoxNews.com,2012.

10. Goyal, M., Mehta, R. L., Schneiderman, L. J., \& Sehgal, A. R. Economic and health consequences of selling a kidney in India. The Journal of American Medical Association, 2012; 288(13),1589-1593. 
11. Bakdash $\mathrm{T}$, Scheper-Hughes N. Is it ethical for patients with renal disease to purchase kidneys from the world's poor?P LoS Medicine. 2006 0ct;3(10):e349. Review. PubMed PMID: 17076548; PubMed Central PMCID: PMC1621090.

12. Lundin S. Organ economy: organ trafficking in Moldova and Israel. Public Understanding of Science, 2012; 21(2), 226-41. PubMed PMID: 22586847.

13. Demeny, E. "Report on Hungary and Romania, Draft 27/8 2009." Ethical, legal and psychosocial aspects of organ transplantation (ELPAT) Working Group on Organ Trafficking, Tourism and Paid Donation, Rotterdam, The Netherlands 2009.

14. Fasting, U., Christensen, J., \& Glending, S. Children sold for transplants: Medical and legal aspects. Amnesty International-Danish Working Group for Children, Denmark, 1998; 5, 518-526.

15. Brian, K. Black market in transplant organs. New York
Daily News, August 25, 2002.

16. Furlow B. Solid organ donation and transplantation. Radiologic Technology, 2012;73(4).

17. Hippen, B., Ross, L. F., \& Sade, R. M. Saving lives is more important than abstract moral concerns: Financial incentives should be used to increase organ donation. The Annals of Thoracic Surgery, 2009; 88, 1053-1061.

18. Ambagtsheer, A., \& Weimar, W. A criminological perspective: Why prohibition of organ trade is not effective and how the declaration of Istanbul can move forward. American Journal of Transplantation, 2012;12, 671-676. doi: doi: 10.1111/j.16006143.2011.03864.x

19. Bruzzone, P. Financial incentives for organ donation: A slippery slope toward organ commercialism? Transplantation Proceedings, 2010;42(4), 1048-1049. doi: 10.1016/j.transproceed.2010.03.058.

\section{AUTHOR(S):}

1. DR. MUHAMMAD NASIR

(601 S Roosevelt Ave, Fullerton, CA, 92832)

2. DR. TEHMINA NASIR

(601 S Roosevelt Ave, Fullerton, CA, 92832)

3. DR. HIRA ASHRAF KHAN

(107 Al Atta Colony, PO Gulgasht, Bosan Road, Multan)

4. Dr. Saba Khizar

(House \# D-58, FFC, Goth Machii, Sadiqabad,

Distt Rahim Yar Khan)
Correspondence Address:

Dr. Muhammad Nasir

MBBS, MPHC, RDMS, RVT, RDCS

Director Medical Programs, South Coast College,

Orange, CA 92868, USA

Research Assistant, California State University,

Fullerton, CA, USA

drnasir77@gmail.com
Article received on: $01 / 01 / 2013$ Accepted for Publication: $20 / 01 / 2013$ Received after proof reading: 06/02/2013

\section{CORRECTION}

The amendment of the Professional Vol:19, No.06 (Prof-1981) titled: "Maternal morbidity and mortality; association with unsafe abortion" on page 797 is as under;

\section{INCORRECT}

DR. SALMA JABEEN, MCPS, FCPS

Senior Registrar,

Department of Obstetrics \& Gynaecology,

Bahawal Victoria Hospital, Bahawalpur

\section{CORRECT}

DR. SALMA JABEEN, MCPS, FCPS

Assistant Professor,

Department of Obstetrics \& Gynaecology,

Quaid-e-Azam Medical College, Bahawalpur 